\title{
Rooting of Mesquite (Prosopis) Cuttings
}

\author{
PETER FELKER AND PETER R. CLARK
}

\begin{abstract}
Natural mesquite stands and other seed-propagated mesquite are extremely variable because of mesquite's obligately outcrossed breeding mechanism. Clonal propagation methods are required to reduce genetic variation in controlled experiments and for propagation of ornamentals. Cuttings of six species of Prosopis (mesquite) representing Hawaiian, North American, and South American germplasm were successfully rooted using a translucent high humidity chamber, greenhouse-grown cutting stock, a foliar dithane (fungicide) spray, and a $3 \mathrm{sec} .100 \%$ dimethylsulfoxide dip containing $(\mathrm{mg} / \mathrm{L})$ :indolebutyric acid $(6,000)$, napthaleneacetic acid $(9,000)$, boric acid $(100)$, calcium chloride $(200)$, thiamine (100), and Banrot (100).
\end{abstract}

Self-incompatibility in mesquite (Prosopis spp.) (Simpson 1977) causes outcrossing so that trees propagated from seed are extremely variable. We have observed coefficients of variation as high as $70 \%$ for mesquite biomass production in deliberately planted even-aged mesquite stands (Felker et al. 1981). Vegetative propagation techniques are necessary to reduce genetic variability in controlled greenhouse and field experiments. Several reports of vegetative propagation of rangeland and desert shrubs have appeared (Chase and Strain 1966; Everett et al. 1979; Nord and Goodin 1970; and Wieland et al. 1971); however, the only report of mesquite vegetative propagation is a negative one (Chase and Strain 1966). We report the first successful rooting of mesquite cuttings.

\section{Methods}

The origins of these plants, with two exceptions, are described in a previous publication (Felker et al. 1981). Accession 0351 originated from a cutting of a 25 -year old, $17.5 \mathrm{~m}$ tall ornamental tree of South American origin growing near Indio, California, and accession 0352 originated from a cutting of a $4 \mathrm{~m}$ tall, 1.75-year old $P$. alba growing in a plot on the University of California, Riverside Agricultural Experiment Station.

Plants used for cuttings in Table 1 were grown in pots in the greenhouse and were approximately a year old with a maximum height of about $2 \mathrm{~m}$. Each cutting contained two nodes with the leaves removed from the lower node. All cuttings for each species came from the same plant and were taken from the tip back until brown wood was encountered. Cuttings were given a 3-second dip to a depth of 1 to $2 \mathrm{~mm}$ in the hormone solution before they were stuck in vermiculite filled pots. Plastic pots approximately $13 \times 13$ $\times 13 \mathrm{~cm}$ were used. Each pot $\left(160 \mathrm{~cm}^{2}\right.$ surface area) received $80 \mathrm{ml}$ of a $500 \mathrm{mg} / \mathrm{L}$ Banrot ${ }^{\mathrm{T}}$ suspension. The average diameter and length of cutting were 3 and $60 \mathrm{~mm}$ respectively. The $P$. alba cuttings were longer $(10 \mathrm{~cm})$ and thicker and did not callus to the extent of the other cuttings. Use of larger cuttings for $P$. alba was unavoidable because the distance between nodes was longer than

\footnotetext{
Authors arc assistant research scientist, Caesar Kleberg Wild life Research Institute, Texas A\&I University, Kingsville, Texas 78363 ; and staff research associate, Department of Soil and Environmental Sciences, University of California, Riverside, California 92521 .

The financial assistance of U.S. Department of Energy Grant No. ET-78-G-01-3074 is gratefully acknowledged.

Received for publication December 30, 1979.
}

for other species. The cuttings were evaluated after 3 weeks.

The plastic pots were placed in a translucent high humidity tent chamber with a thermostatically controlled evaporative cooler. The tent chamber was located in the greenhouse. A $10 \mathrm{~g} / \mathrm{L}$ Dithane suspension was sprayed on all cuttings in Tables 2 and 3 and markedly reduced problems with the fungus alternaria. For mature trees terminal branches were cut to 50-cm lengths, misted with a Dithane suspension, the ends placed in water, and transported in a portable, ice-filled cooler. Within $2 \mathrm{hr}$ after collection, two node cuttings were made and the hormone treatment applied. The indole amino acid conjugates were graciously provided by $\mathbf{R}$. Hangarter, Dept. Botany and Plant Pathology, Michigan State University, East Lansing, Michigan 48824.

\section{Results and Discussion}

The results of initial screening trials using $2 \mathrm{~N} \mathrm{H}_{2} \mathrm{SO}_{4}$ predips (Lee et al. 1976), osmocote (Gouin 1974), ethrel (Swanson 1974) wounding (Howard 1973) and various auxins led to a hormonal dip consisting of in $(\mathrm{mg} / \mathrm{L})$ : indolebutyric acid-6,000; naphthaleneacetic acid-9,000; boric acid-100, $\mathrm{CaCl}_{2} \cdot 2 \mathrm{H}_{2} 0-200$, thiamine-100; Banrot ${ }^{\mathrm{Tm}}-100$. The solvent was $70 \%$ ethanol since lower ethanol concentrations would not dissolve the naphthalene acetic acid. The cutting solution was stored in the freezer and discarded if it became yellow.

Daytime relative humidities of only $60 \%$ were achieved in this chamber, and thus two pots were covered with a polyethylene bag and two pots were left uncovered. As shown in Table 1, six species of widely divergent origins gave at least $70 \%$ successful rooting when using a polyethylene cover and the hormone mix described above. The polyethylene cover over individual pots did not seem to be very helpful except for the clone of the ornamental Prosopis (0351). When all the species were considered together, the number of roots/cutting and the length of the longest root/cutting were significantly greater $(5 \%$ level) in the covered treatment. Successful use of this technique is not restricted to a few special species or accessions since on the average eight roots of maximum length of 8 $\mathrm{cm}$ were obtained in 3 weeks from widely divergent plant species.

Dimethylsulfoxide (DMSO) was substituted for $70 \%$ ethanol because DMSO is less volatile and because DMSO can tolerate more water from wet plant stems without causing precipitation of NAA and IBA.

A comparison of the root-inducing properties of three strengths of a commercially available rooting formulation (cutstart $\mathbf{x x}, \mathbf{x x x}$, and $\mathrm{xxxx}$ ) that is very effective in rooting jojoba (Simmondsia chinensis) cuttings (Yermanos, pers. comm) with the formulation described here is presented in Table 2 . The length of the longest root did not appear to be significantly different among treatments but the formulation we developed gave a greater percentage rooting and a greater number of roots per cutting.

The technique reported here has its shortcomings since even in the greenhouse it works better in the spring than in the summer or fall. In the spring $100 \%$ of cuttings from clone 0351 rooted as reported in Table 1 but only $15 \%$ rooted in November. Some environmental-plant hormone interaction appears to be regulating cutting success for greenhouse-grown seedlings since, at a particu- 
Table 1. Rooting ability among widely divergent Prosopis species.

\begin{tabular}{|c|c|c|c|c|}
\hline $\begin{array}{l}\text { Species (accession number) } \\
\text { (Origin) }\end{array}$ & & Percent rooted & $\begin{array}{l}\text { Number roots per number } \\
\text { attempted }\end{array}$ & $\begin{array}{l}\text { Length longest root per } \\
\text { number attempted } /(\mathrm{cm})\end{array}$ \\
\hline $\begin{array}{l}P . \text { alba }(0352) \\
\text { (Argentina) }\end{array}$ & $\begin{array}{r}\text { covered } \\
\text { uncovered }\end{array}$ & $\begin{array}{l}80 \\
30\end{array}$ & $\begin{array}{l}4.4 \mathrm{a}^{1} \\
1.6 \mathrm{a}^{2}\end{array}$ & $\begin{array}{l}3.4 \mathrm{a} \\
1.1 \mathrm{a}\end{array}$ \\
\hline $\begin{array}{l}\text { P. articulata (0016) } \\
\text { (Mexico) }\end{array}$ & $\begin{array}{r}\text { covered } \\
\text { uncovered }\end{array}$ & $\begin{array}{r}100 \\
90\end{array}$ & $\begin{array}{l}6.5 \mathrm{a} \\
7.0 \mathrm{a}\end{array}$ & $\begin{array}{l}12.6 \mathrm{a} \\
10.6 \mathrm{a}\end{array}$ \\
\hline $\begin{array}{l}\text { P. chilensis (0009) } \\
\text { (Argentina) }\end{array}$ & $\begin{array}{l}\text { covered } \\
\text { uncovered }\end{array}$ & $\begin{array}{r}90 \\
100\end{array}$ & $\begin{array}{r}9.0 \mathrm{a} \\
12.2 \mathrm{a}\end{array}$ & $\begin{array}{r}6.4 \mathrm{a} \\
12.2 \mathrm{~b}\end{array}$ \\
\hline $\begin{array}{l}\text { P. glandulosa var torreyana } \\
(0001) \\
\text { (California) }\end{array}$ & $\begin{array}{r}\text { covered } \\
\text { uncovered }\end{array}$ & $\begin{array}{l}90 \\
70\end{array}$ & $\begin{array}{l}14.1 \mathrm{a} \\
11.4 \mathrm{a}\end{array}$ & $\begin{array}{r}10.4 \mathrm{a} \\
7.2 \mathrm{a}\end{array}$ \\
\hline $\begin{array}{l}P . \text { pallida }(0041) \\
\text { (Hawaii) }\end{array}$ & $\begin{array}{r}\text { covered } \\
\text { uncovered }\end{array}$ & $\begin{array}{l}90 \\
80\end{array}$ & $\begin{array}{r}10.0 \mathrm{a} \\
6.0 \mathrm{a}\end{array}$ & $\begin{array}{l}7.9 \mathrm{a} \\
6.6 \mathrm{a}\end{array}$ \\
\hline $\begin{array}{l}P . \text { velutina }(0020) \\
\text { (Arizona) }\end{array}$ & $\begin{array}{r}\text { covered } \\
\text { uncovered }\end{array}$ & $\begin{array}{l}70 \\
50\end{array}$ & $\begin{array}{l}6.8 \mathrm{a} \\
3.2 \mathrm{a}\end{array}$ & $\begin{array}{l}7.4 \mathrm{a} \\
3.5 \mathrm{a}\end{array}$ \\
\hline P. spp (0351) & $\begin{array}{r}\text { covered } \\
\text { uncovered }\end{array}$ & $\begin{array}{r}100 \\
30\end{array}$ & $\begin{array}{l}6.6 \mathrm{~A} \\
0.9 \mathrm{~B}\end{array}$ & $\begin{array}{l}8.2 \mathrm{~A} \\
0.7 \mathrm{~B}\end{array}$ \\
\hline All varieties & $\begin{array}{r}\text { covered } \\
\text { uncovered }\end{array}$ & $\begin{array}{l}88 \\
64\end{array}$ & $\begin{array}{l}8.20 \mathrm{a} \\
6.04 \mathrm{~b}\end{array}$ & $\begin{array}{l}8.04 \mathrm{a} \\
5.98 \mathrm{~b}\end{array}$ \\
\hline
\end{tabular}

'Mean separation by Duncans multiple range test was only performed within a species for covered and uncovered. Means followed by same small (or capital) letter are not different at $5 \%$ (or $1 \%$ ) level.

Table 2. Comparison of rooting formulation described here with a commercially available rooting formulation. ${ }^{1}$

\begin{tabular}{lllll}
\hline \hline $\begin{array}{l}\text { Hormone } \\
\text { treatment }\end{array}$ & Replicate & $\begin{array}{c}\% \\
\text { rooted }\end{array}$ & $\begin{array}{l}\text { Length } \\
\text { longest root } \\
\text { (cm) }\end{array}$ & $\begin{array}{l}\text { Number of } \\
\text { roots }\end{array}$ \\
\hline $\begin{array}{l}\text { Formulation } \\
\text { described here }\end{array}$ & 1 & 60 & $12.6 \pm 7.9$ & $8 \pm 4.9$ \\
& 2 & 80 & $9.6 \pm 6.0$ & $6.6 \pm 4.6$ \\
& 3 & 73 & $10.5 \pm 3.2$ & $11 \pm 9.9$ \\
Cutstart xx & 1 & 20 & $7.5 \pm 3.5$ & $1 \pm 0$ \\
& 2 & 30 & $9.1 \pm 6.9$ & $2.7 \pm 2.0$ \\
& 3 & 30 & $17 \pm 3.0$ & $2.3 \pm 1.1$ \\
Cutstart xxx & 1 & 30 & $5.7 \pm 8.9$ & $1.3 \pm 0.6$ \\
& 2 & 61 & $14 \pm 3.9$ & $2.1 \pm 1.1$ \\
& 3 & 33 & $15 \pm 5.2$ & $2.5 \pm 1.7$ \\
Cutstart xxxx & 1 & 31 & $12.1 \pm 5.6$ & $1.0 \pm 0$ \\
& 2 & 64 & $10.7 \pm 3.3$ & $2.4 \pm 1.3$ \\
& 3 & 50 & $10.7 \pm 6.3$ & $1.8 \pm 1.3$ \\
\hline
\end{tabular}

'Cuttings were taken from greenhouse grown orna mental mesquite of accession 0351 . Ten cuttings per replicate were used.

lar time, all species root well or not at all.

Indoleacetic acid (IAA) predominantly exists in legume seeds in the form of amide linked IAA-amino acid conjugates, which unlike free IAA are immune to attack by peroxidases (Cohen and Bandurski 1978). Several of these IAA and IBA conjugates were examined for their capability to overcome the recalcitrant nature of out-of-doors grown trees to initiate roots from cuttings (Table 3). When using a greenhouse-grown stock material, little differences in the rooting of cuttings made with indolebutyric compounds were noted although a lower number of roots per cutting were observed with the indoleacetic compounds. The IBA-alanine treated cuttings had greener looking leaves and appeared to have a more fibrous root system than other treatments. None of these compounds were effective in rooting cuttings of an out-of-doors grown 3-year-old $P$. velutina that was similar to the $P$. velutina successfully rooted in Table 1. Repeated attempts throughout the growing season to obtain cutting from a specific mature out-ofdoors grown Prosopis generally will be successful in obtaining one
Table 3. Effect on indoleamino acid conjugates on rooting of mesquite cuttings.

\begin{tabular}{|c|c|c|c|}
\hline Hormone Used ${ }^{2}$ & $\begin{array}{c}\% \\
\text { rooted }\end{array}$ & $\begin{array}{l}\text { Average number } \\
\text { of roots } \\
\text { per cutting } 1\end{array}$ & $\begin{array}{l}\text { Length longest } \\
\text { root per } \\
\text { cutting }\end{array}$ \\
\hline \multicolumn{4}{|c|}{$\begin{array}{l}\text { A. Using stock material from } 7 \mathrm{ft} \text {. tall clonal plants (accession 0351) in } \\
\text { greenhouse. }\end{array}$} \\
\hline indolebutyric acid & 40.6 & $7.1 \pm 3.0$ & $15.9 \pm 3.6$ \\
\hline $\begin{array}{l}\text { indolebutyryl- } \\
\text { phenylalanine }\end{array}$ & 53.1 & $5.4 \pm 4.0$ & $10.7 \pm 6.1$ \\
\hline indolebutyryl-alanine & 53 & $7.3 \pm 3.9$ & $15.3 \pm 5.3$ \\
\hline doleacetvl-alanine & 50.0 & $2.2 \pm 1.6$ & $14.4 \pm 4.9$ \\
\hline indoleacetyl-leucine & 37.5 & $2.0 \pm 1.3$ & $12.7 \pm 4.4$ \\
\hline
\end{tabular}

B. Using stock material from 3-year-old tree $(P$. velutina) out-of-doors. Zero percent rooting for all treatments (no rooted cuttings from 160 cuttings).

'For each treatment 4 pots with 8 cuttings were used ( 4 replicates). Computation of average number of roots and length longest root is for those cuttings which rooted (not divided by 32 ).

${ }^{2}$ Mixture was composed of naphthalene acetic acid $9,000 \mathrm{mg} / \mathrm{L}$; boric acid, $200 \mathrm{mg} / \mathrm{L}$; thiamine, $200 \mathrm{mg} / \mathrm{L}$; Banrot, $200 \mathrm{mg} / \mathrm{L}$; $\mathrm{CaCl}_{2} \bullet 2 \mathrm{H}_{2} 0,200 \mathrm{mg} / \mathrm{L}$, and the hormone indicated. IBA was used at $6,000 \mathrm{mg} / \mathrm{L}$ and other hormones were used at equivalent molarities. Mixture was dissolved in 100\% DMSO and used as a 3 sec. dip.

or two rooted cutting if liberal use of dithane spray and thorough disinfection of cutting tools with ethanol is practiced. The rooted cuttings obtained can be grown under optimal greenhouse conditions where rooting percentages of $50 \%$ or more can often be obtained.

The first report of rooting of mesquite cuttings can be very successful if carried out in the spring of the year using young trees with actively growing foliage. More research will be required to allow successful propagation of mesquite all year round from young and old trees.

\section{Literature Cited}

Chase, V.C., and B.R. Strain. 1966. Propagation of some woody desert perennials by stem cuttings. Madrono 18:240-243.

Cohen, J.D., and R.S. Bandurski. 1978. The bound auxins: Protection of indole-3-acetic acid from peroxidase-catalyzed oxidation. Planta 139, 203-208. 
Everett, R.L., R.O. Meeuwig, and J.O. Robertson. 1978. Propagation of Nevada shrubs by stem cuttings. J. Range Manage. 31:426-429.

Felker, P., G.H. Cannell, and P.R. Clark. 1981. Variation in growth among 13 Prosopis (mesquite) species. Expl. Agr. 17:209-218.

Gouin, F.R. 1974. Osmocote in the propagation house. Proc. Internat. Plant Prop. Soc. 24:337-341

Howard, B.H. 1973. A measure of the consistency of the response of cuttings to propagation treatments as a guide to the value of experiments on nurseries. Proc. Internat. Plant Prop. Soc. 23:203-209.

Lee, C.I., J.L. Paul, and W.P. Hackett. 1976. Root promotion on stem cuttings of several ornamental plant species by acid or base treatment.
Proc. Internat. Plant Prop. Soc. 26:95-99.

Nord, E.C., and J.R. Goodin. 1970. Rooting cuttings of shrub species for plantings in California wildlands. U.S. Dep. Agr. Forest Serv. Res. Note. PSW-213.

Simpson, B.B. 1977. Breeding systems of dominant perennial plants of two disjunct warm desert ecosystems. Oecologia (Berl.) 27:203-226.

Swanson, B.T. 1974. Ethrel as an aid in rooting. Proc. Internat. Plant Prop. Soc. 24:351-361.

Wieland, P.A.T., E.F. Frolich, and A. Wallace. 1971. Vegetative propagation of woody shrub species from the Northern Mojave and Southern Great Basin deserts. Madrono 21:149-152. 